\title{
Sistem Penjadwalan Mesin Produksi Menggunakan Algoritma Johnson dan Campbell
}

\author{
Fifin Sonata \\ Program Pascasarjana Jurusan Teknik Informatika \\ Fakultas Ilmu Komputer dan Teknologi Informasi, Universitas Sumatera Utara \\ Jalan Universitas No. 24 A, Kampus USU Medan 20155, Sumatera Utara \\ E-mail: fifinsonata2012@gmail.com
}

Masuk: 6 September 2014; Direvisi: 14 Oktober 2014 dan 28 Oktober 2014; Diterima: 29 Oktober 2014

\begin{abstract}
Scheduling production machine has an essential role in minimizing the makespan in order to raise the production efficiency. Makespan generated from more than one production machines, can still wait for jobs in the processsince the job is still in the process on another machine, or as a job waiting to be processed by a machine because the machine is still processing another job. The methode applied for flow shop and static production system is Integrated Algorithm which combines Johnson and Campbell Algorithm. By applying these two methods to the company, the company can see the schedule of the production machine that gives the minimum makespan in a computerized system. The presentation is in the form of tables mapping to facilitate the search makespan.
\end{abstract}

Keywords: Production Machine Scheduling, Flow Shop, Static, Makespan, Johnson and Campbell Algorithm.

\begin{abstract}
Abstrak. Penjadwalan mesin produksi memiliki peran yang sangat penting dalam meminimalkan makespan sehingga efisiensi produksi dapat tercapai. Makespan yang dihasilkan untuk jumlah mesin produksi lebih dari satu mesin, masih mungkin mengandung waktu tunggu karena sebuah mesin kemungkinan menunggu job yang harus diprosesnya, sementara job tersebut masih diproses pada mesin yang lain, atau karena sebuah job menunggu untuk diproses oleh sebuah mesin karena mesin tersebut masih memproses job yang lain. Proses $N$ Jobs M Mesin terdapat lebih dari 1 makespan tetapi yang dipilih adalah makespan terkecil. Metode yang dapat digunakan pada sistem produksi yang flow shop dan statis adalah algoritma kombinasi dari Algoritma Johnson dan Campbell. Dengan menerapkan dua metode tersebut pada perusahaan maka perusahaan dapat mengetahui jadwal mesin produksi yang memberikan makespan paling minimum secara terkomputerisasi. Penyajian dalam bentuk pemetaan tabel mempermudah dalam pencarian makespan.
\end{abstract}

Kata kunci: Penjadwalan Mesin Produksi, Flow shop, Statis, Makespan, Algoritma Johnson dan Campbell.

\section{Pendahuluan}

Setiap perusahaan yang bergerak dalam bidang produksi pasti melaksanakan program peningkatan produktivitas. Dalam melaksanakan aktivitasnya perusahaan harus melakukan penjadwalan mesin produksi yang baik. Perusahaan yang berproduksi berdasarkan job order dituntut untuk selalu dapat memenuhi permintaan konsumen pada waktu yang telah disepakati. Namun banyaknya jenis produk yang dipesan oleh para konsumen dapat selesai dalam waktu yang bersamaan seringkali membuat kesulitan pihak perusahaan dalam melakukan penjadwalan terhadap prioritas jenis produk yang harus diproduksi terlebih dahulu. Selama ini produkproduk yang dipesan oleh konsumen dapat dipenuhi oleh perusahaan, baik dari segi kualitas maupun kuantitas namun membutuhkan waktu yang cukup lama sehingga tidak jarang terjadi keterlambatan. 
Algoritma Jhonson dan Campbell merupakan salah satu metode yang dapat digunakan dalam mengatasi keterlambatan tersebut dengan kategori penjadwalan mesin produksi yang flowshop dan statis yang dapat meminimumkan makespan untuk pengerjaan produk $(\mathrm{N}$ job) dengan berbagai mesin (M Mesin). Dalam pengerjaan N Jobs 1 Mesin dan N Jobs 2 mesin alternatif yang digunakan yaitu metode Johnson untuk mesin dengan jumlah diatas dua menggunakan metode Campbell. Sedangkan metode Campbell merupakan pengembangan dari metode Johnson.

\section{Tinjauan Pustaka}

\subsection{Penjadwalan Mesin Produksi}

Penjadwalan mesin produksi adalah salah satu mata rantai kegiatan dari perencanaan produksi, dimana kegiatan penjadwalan itu sendiri berkaitan dengan proses pengurutan pengerjaan produk secara menyeluruh pada beberapa mesin. Metode pada penjadwalan ini adalah algoritma yang dapat memberikan hasil yang cukup baik walaupun belum optimal. Tetapi dengan semakin berkembangnya kebutuhan akan penjadwalan yang semakin efisien, maka semakin penting untuk menghasilkan jadwal yang lebih baik dan mencapai solusi yang mendekati optimal.

Pada beberapa perusahaan, kesalahan dalam menyusun penjadwalan produksi tidak hanya dapat mengacaukan usaha pengawasan mesin produksinya, tetapi juga mempengaruhi jumlah produksi perusahaan. Penyusunan suatu penjadwalan mesin produksi yang semata-mata hanya berdasarkan pada intuisi belaka jelas akan dapat mempengaruhi jumlah hasil produksi yang sebenarnya maupun yang dihasilkan. Dalam hal ini penjadwalan produksi yang demikian itu akan menyebabkan timbulnya waktu yang tidak produktif dari mesin-mesin yang digunakan dalam proses produksi ini jelas merupakan faktor yang dapat merugikan perusahaan.

Suatu penjadwalan mesin produksi yang berdasarkan pada suatu pemikiran yang ilmiah jelas akan mengurangi timbulnya hal-hal yang merugikan perusahaan sehubungan dengan penjadwalan mesin produksinya (Christianta dkk., 2012). Dengan penjadwalan produksi yang baik tentunya mesin-mesin yang digunakan dapat dioperasikan sesuai dengan kapasitas yang dimiliki dan memperkecil kemungkinan timbulnya waktu yang tidak produktif dari mesin-mesin tersebut. Namun demikian setidak-tidaknya dengan suatu penjadwalan produksi yang baik dan tepat, maka hasil produksi relatif akan lebih tinggi jika dibandingkan dengan penjadwalan mesin produksi yang hanya berdasarkan intuisi saja.

Dalam pembuatan jadwal harus diketahui lebih dahulu adalah kapasitas produksi mesin diukur berdasarkan bermacam-macam aturan yang dapat digunakan, diantaranya: (1) First Come First Server (FCFS) dimana urutan pekerjaan diproses berdasarkan urutan order/pesanan yang masuk. (2) Shortest Processing Time (SPT) dimana urutan pekerjaan dipilih berdasarkan waktu proses yang paling singkat. (3) Longest Processing Time (LPT) dimana urutan pekerjaan dipilih berdasarkan waktu proses yang paling lama. Adapun fungsi pokok penjadwalan mesin produksi adalah untuk membuat arus produksi dapat berjalan lancar sesuai dengan waktu yang direncanakan.

\subsection{Macam Penjadwalan Produksi}

Penjadwalan secara garis besar berdasarkan urutan proses produksinya dapat dibedakan dalam 2 macam yaitu (Masruroh, 2008), pertama, Job Shop adalah pola alir dari N job melalui $\mathrm{M}$ mesin dengan pola aliran sembarang dan proses pengurutan pekerjaan untuk lintasan produk yang tidak beraturan. Penjadwalan pada proses produksi job shop salah satu ciri-cirinya adalah bentuk tata letak job shop biasanya digolongkan dari peralatan yang mempunyai fungsi yang mirip di suatu area (Badworth, 1987), sebagaimana diilustrasikan pada Gambar 1.

Yang kedua, Flow Shop adalah proses penentuan urutan pekerjaan yang memiliki lintasan produk yang sama atau hampir sama. Pada dasarnya ada beberapa macam pola flow shop, antara lain: (Farouq, 2013), (a) Pure Flow Shop, Flow shop yang memiliki jalur produksi yang sama untuk semua tugas. Mesin disusun sesuai dengan alur proses yang ada dimana sebuah job diharuskan menjalani satu kali proses untuk tiap-tiap kondisi. Bentuk Pure Flow 
Shop diilustrasikan pada Gambar 2. (b) General Flow Shop memiliki pola aliran berbeda, dimana pada pola alir General Flow Shop ini mempunyai ciri-ciri: Alur proses selalu menunjukkan arah ke kanan, urutan operasi boleh tidak berurutan, tidak diperbolehkan adanya alir proses balik. General Flow Shop diilustrasikan pada Gambar 3.

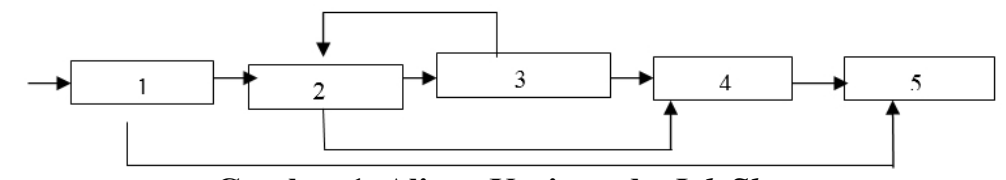

Gambar 1. Aliran Kerja pada Job Shop

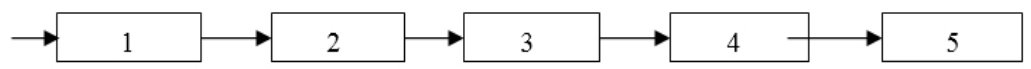

Gambar 2. Aliran Kerja pada Pure Flow Shop

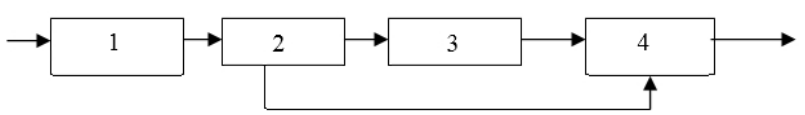

Gambar 3. Aliran Kerja pada General Flow Shop

\subsection{Penjadwalan Job pada Mesin}

Penetapan penjadwalan atau urutan job pada suatu produksi akan memberikan keuntungan: (1) Tenaga manusia dan mesin beserta kelengkapannya dapat digunakan seefektif mungkin. (2) Keterlambatan dan kemacetan dalam proses produksi dapat ditekan sekecil mungkin. (3) Penggunaan produksi dapat dilaksanakan dengan baik dengan cara membandingkan pelaksanaan produksi dan rencana urutan yang telah disusun. (4) Total waktu dan proses secara keseluruhan dapat dicari sampai seminimal mungkin. (5) Keseimbangan dari operasi dapat dilaksanakan dengan baik.

Penyelesaian dalam masalah penjadwalan ini dapat diklasifikasikan menurut jumlah mesin dan job yang dijadwalkan menjadi tiga macam yaitu: (1) Penjadwalan untuk N Jobs, 1 Mesin. (2) Penjadwalan untuk N Jobs, 2 Mesin. (3) Penjadwalan untuk N Jobs, M Mesin.

Beberapa istilah umum yang digunakan dalam membahas masalah penjadwalan produksi (Aryetta, 2007): (1) Waktu pengerjaan atau Processing Time $\left(\mathrm{t}_{\mathrm{ij}}\right)$ adalah waktu yang dibutuhkan untuk menyelesaikan suatu pekerjaan/job ke-i pada mesin ke-j. (2) Waktu tunggu atau Waiting Time $\left(\mathrm{W}_{\mathrm{ij}}\right)$ adalah waktu yang dipergunakan oleh job/pekerjaan ke-i sebelum job tersebut diproses pada suatu mesin ke-j. (3) Batas akhir atau Due Date $\left(\mathrm{d}_{\mathrm{i}}\right)$ adalah waktu yang diberikan setiap job/pekerjaan ke-i sebagai batas penyelesaian pekerjaan. (4) Allowance time $\left(\mathrm{a}_{\mathrm{i}}\right)$ adalah waktu longgar untuk proses diantara waktu ready/siap $\left(\mathrm{r}_{\mathrm{i}}\right)$ sampai dengan due date. (5) Waktu keseluruhan atau Completion time $\left(\mathrm{C}_{\mathrm{i}}\right)$ adalah waktu yang diberikan pada setiap job/pekerjaan ke-I sebagai batas penyelesain pekerjaan. (6) Waktu keterlambatan atau Lateness Time $\left(\mathrm{L}_{\mathrm{i}}\right)$ adalah selisih dari completion time dikurangi due date. (7) Tardiness $\left(\mathrm{T}_{\mathrm{i}}\right)$ adalah job yang terlambat diserahkan ke konsumen. (8) Earliness $\left(\mathrm{E}_{\mathrm{i}}\right)$ adalah penyelesaian job lebih cepat dari batas waktu yang ditentukan. (9) Makespan $\left(\mathrm{M}_{\mathrm{s}}\right)$ adalah waktu penyelesaian seluruh job pada shop.

\subsection{Penjadwalan N Jobs 1 Mesin}

Ada beberapa aturan yang dipakai dalam menyelesaikan penjadwalan job pada satu mesin ini begitu pula dengan kriteria penyelesaian yang digunakan (Ginting, 2009): (1) Aturan SPT (Short Prosessing Time) dimana cara pengurutan job didasarkan pada waktu proses terkecil, yaitu job yang mempunyai waktu proses yang lebih kecil yang didahulukan yaitu $\mathrm{t}_{1}, \mathrm{t}_{2}$ , $\mathrm{t}_{3}, \mathrm{t}_{\mathrm{n}}$. (2) Aturan EDD (Earliest Due Date) dimana pengurutan job didasarkan atas nilai d-nya, dimana $\mathrm{d}_{1}, \mathrm{~d}_{2}, \mathrm{~d}_{3}, \ldots, \mathrm{d}_{\mathrm{n}}$ dan kriteria yang dipakai adalah meminimasi max $\mathrm{L}_{\mathrm{i}}$. (3) Algoritma Moore and Hudgson dengan langkah-langkah: (a) Urutkan job berdasarkan EDD. (b) Cek apakah job yang terlambat lebih kecil satu, jika ya maka selesai, jika tidak ke langkah 
berikutnya. (c) Identifikasi job yang pertama terlambat dan beri simbol $i^{*}$. (d) Identifikasi $t_{i}$ maksimum dari job pertama pada urutan EDD dengan jobs $\mathrm{i}^{*}$ dan beri simbol $\mathrm{i}^{* *}$. (e) Kesampingkan job i* dari EDD (pindahkan ke urutan EDD terakhir). (f) Kembali ke langkah 2.

\subsection{Penjadwalan $N$ Jobs 2 Mesin - Algoritma Johnson}

Aturan Johnson adalah suatu aturan meminimumkan makespan dua mesin yang disusun paralel dan saat ini menjadi dasar teori penjadwalan (Ginting, 2009). Adapun prosedur Johnson memuat langkah: (1) Dapatkan waktu proses yang lebih kecil. Jika terdapat pada mesin A, tempatkan pekerjaan tersebut sebagai pekerjaan pertama pada mesin A. Jika terdapat pada mesin B tempatkan pekerjaan tersebut sebagai pekerjaan terakhir pada mesin B. (2) Pindahkan pekerjaan yang telah ditempatkan atau ditugaskan dan kembali ke langkah 1. Jika semua pekerjaan telah selesai ditempatkan, maka diperoleh urutan yang optimal. Jika terdapat dua pekerjaan mempunyai waktu sama, pada mesin sama dimana waktu tersebut lebih kecil dari waktu pada mesin lain, maka pembagian penugasan untuk dua pekerjaan tersebut adalah sembarang.

Untuk permasalahan penjadwalan dengan mesin yang lebih dari dua buah, akan sulit dipecahkan dengan metode ini. Untuk mengatasinya, maka digunakan Metode Campbell yang merupakan pengembangan dari metode Johnson.

\subsection{Penjadwalan N Jobs M Mesin}

Penjadwalan $\mathrm{N}$ job $\mathrm{M}$ mesin merupakan sebuah tipe static shop sequencing dimana $\mathrm{n}$ $j o b$ harus diproses oleh $\mathrm{m}$ mesin. Seluruh pekerjaan tersebut diproses di awal periode pengerjaannya, serta tidak ada pekerjaan-pekerjaan baru yang datang selama periode tersebut (static job arrival pattern). Juga pekerjaan-pekerjaan tersebut tidak diperbolehkan saling melewati urutan yang telah ditentukan (pekerjaan-pekerjaan bertahan pada posisi satu urutan yang sama).

Ada teknik secara heuristic mampu memberikan urutan yang baik / urutan yang optimal dalam menyelesaikan problem penjadwalan $\mathrm{N}$ jobs $\mathrm{M}$ machines yaitu metode algoritma Campbell (Dewi dkk, 2005). Metode ini dipakai untuk menjadwalkan N job pada mesin yang lebih dari dua dan merupakan pengembangan dari metode Johnson. Dengan demikian metode Johnson dapat dipakai sebagai dasar perhitungan urutan job pada mesin.

Adapun langkah-langkah pada penjadwalan Campbell (Masruroh, 2008): (1) Identifikasi $\mathrm{k}=1$. Sebagaimana terlihat pada Persamaan 1 dan Persamaan 2. (2) Urutan Job atas Johnson. (3) Hitung $M_{s}$. (4) k=k+1 (5) Periksa apakah $K \geq m$; Jika Ya lanjut ke langkah ke6. Jika Tidak kembali ke langkah ke-2. (6) Pilih $M_{s}$ terkecil dari penjadwalan. (7) Stop.

$$
\text { Hitung: } \quad \begin{aligned}
\quad t_{i j}^{*} & =\sum_{k=1}^{k} t_{j} \cdot k \\
t_{i 2} * & =\sum_{k=1}^{k} t_{i} \cdot m-k+1
\end{aligned}
$$

\section{Metodologi Dan Perancangan}

Pada Gambar 4 dapat dilihat diagram alir algoritma Johnson dan Gambar 5 adalah algoritma Campbell. 


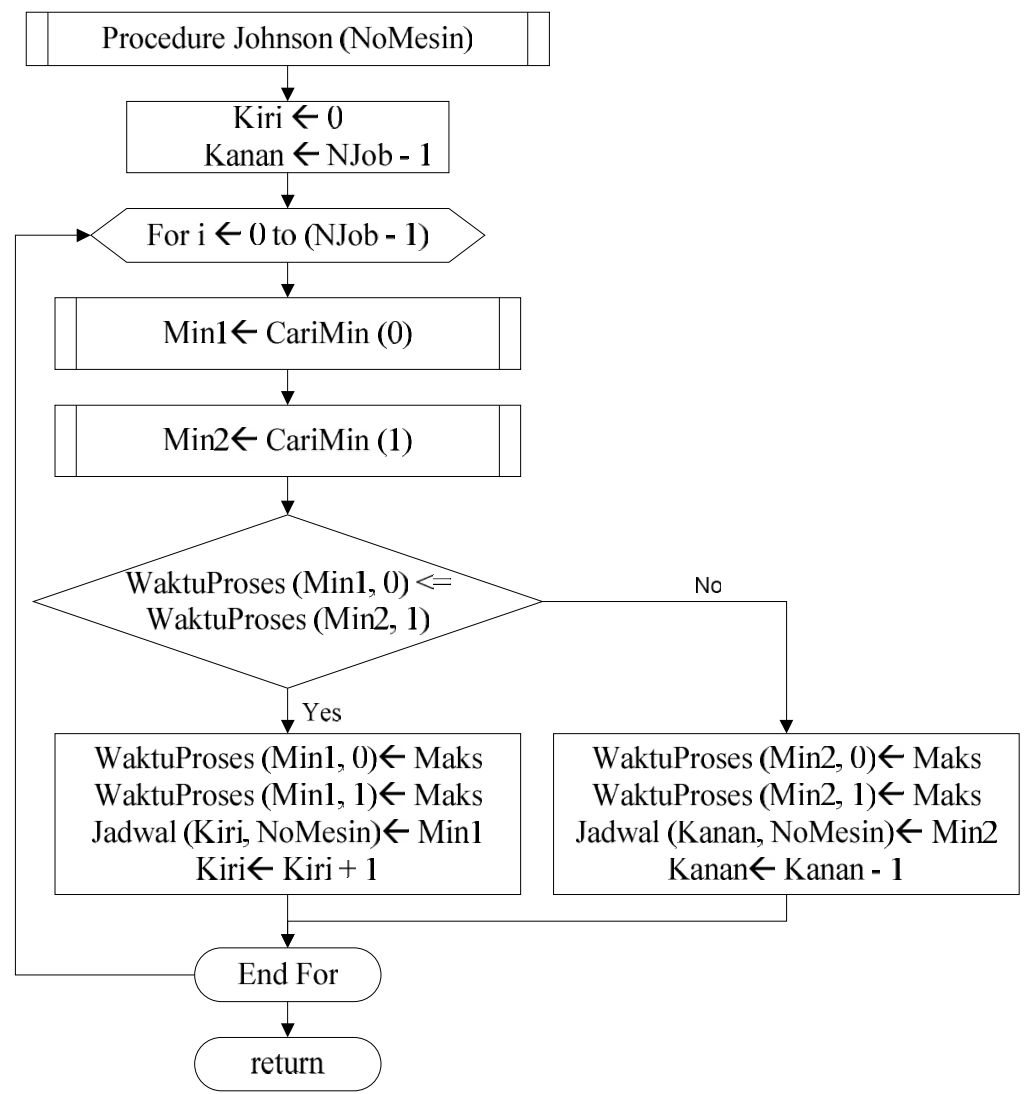

Gambar 4. Diagram Alir Algoritma Johnson

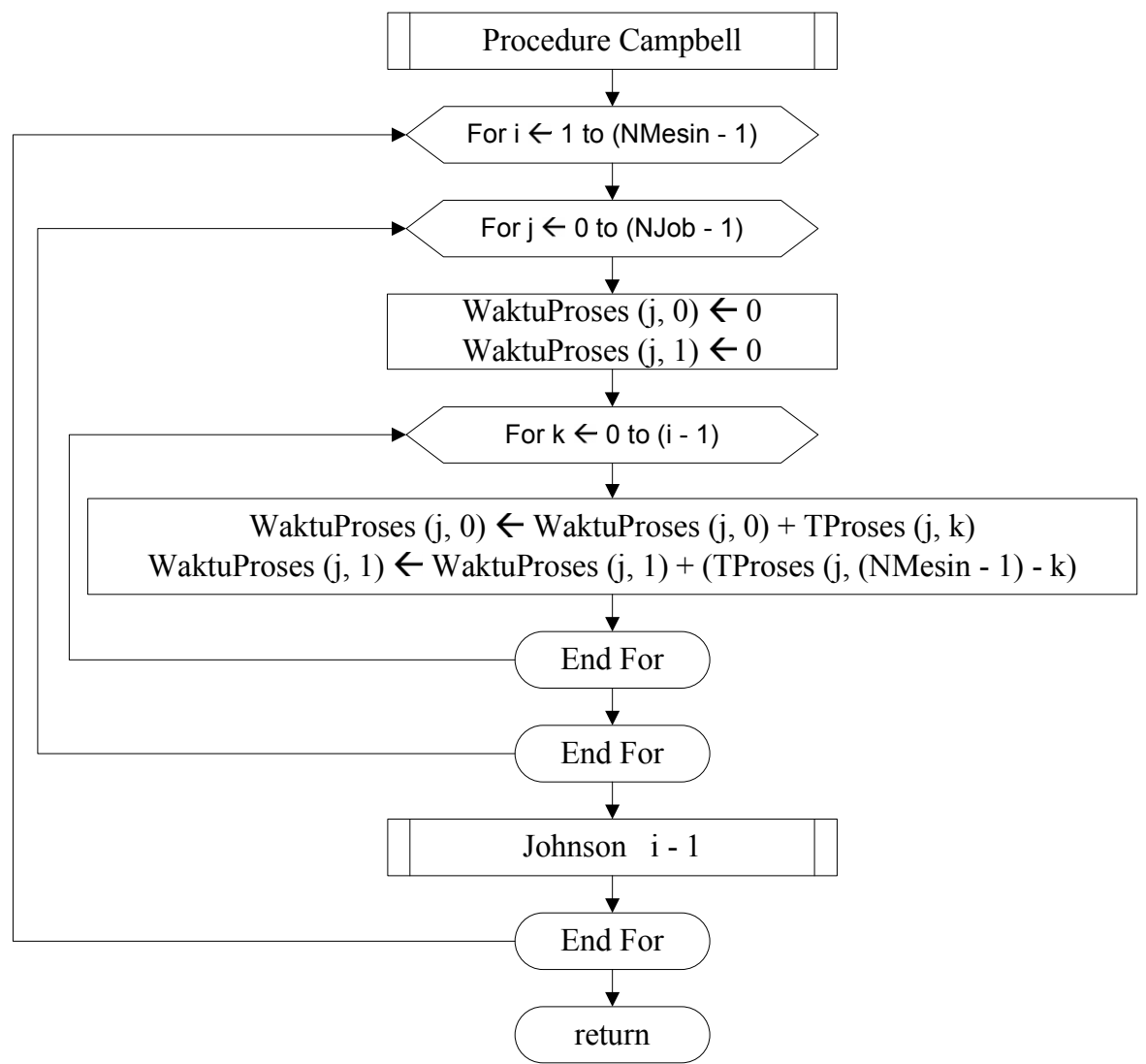

Gambar 5. Diagram Alir Algoritma Campbell 


\subsection{Penjadwalan N Jobs 1 Mesin}

Pada penjadwalan N Jobs 1 Mesin, untuk mendapatkan makespan yang minimum digunakan rumus perhitungan yang terdapat pada Persamaan 3 sampai dengan Persamaan 5.

$$
\begin{aligned}
& t_{[i], j-1}^{N e w}=t_{[i], j-1+I_{[i], j-1}} \\
& I_{[i], j}=\max \left\{0,\left(\sum_{k=1}^{i} t_{[k], j-1}^{\text {New }}-\sum_{k=1}^{i-1} t_{[k], j}-\sum_{k=1}^{i-1} I_{[k], j}\right)\right\} \\
& \text { MS } \quad=\sum_{i=1}^{n} t_{[i], m}+\sum_{i=1}^{n} I_{[i], m} \\
& \text { Dimana MS }=\text { Waktu untuk memproduksi seluruh job hingga selesai } \\
& t_{[i], j} \quad=\text { Waktu proses job urutan ke-i pada mesin ke-j. } \\
& I_{[i], j} \quad=\text { Waktu tunggu job urutan ke-i pada mesin ke-j. }
\end{aligned}
$$

\subsection{Penjadwalan N Jobs 2 Mesin}

Untuk penjadwalan N Jobs 2 Mesin Johnson mengembangkan sebuah algoritma untuk mendapatkan sebuah optimal sequence. Adapun tahapan dari Campbell Johnson yaitu (Novriansyah, 2006): (1) Membuat daftar waktu proses untuk seluruh pekerjaan-pekerjaan tersebut baik pada M-1 atau M-2. (2) Mencari seluruh waktu proses untuk seluruh pekerjaan. Menentukan waktu proses yang minimal. (3) Jika waktu proses minimal berada pada M-1, tempatkan pekerjaan tersebut paling awal dalam urutan. Jika berada pada M-2 maka tempatkan pekerjaan di akhir urutan. (4) Ulangi langkah 2 dan 3 untuk pekerjaan-pekerjaan yang belum dimasukkan ke dalam urutan penjadwalan.

\subsection{Penjadwalan N Jobs M Mesin}

Permasalahan N Jobs M Mesin merupakan sebuah tipe statik shop sequencing dimana $\mathrm{N}$ jobs harus diproses oleh $\mathrm{M}$ mesin. Jumlah pekerjaan ditentukan sebelum proses pengerjaan dimulai, serta tidak ada pekerjaan-pekerjaan baru yang dijadwalkan selama proses produksi (Nurpasca, 2012). Pekerjaan-pekerjaan tersebut tidak boleh menyimpang dari urutan yang telah ditentukan (pekerjaan-pekerjaan mempunyai urutan yang sama). Permasalahannya adalah bagaimana menjadwalkan $\mathrm{n}$ job $\mathrm{m}$ mesin dengan baik agar pekerjaan-pekerjaan tersebut diselesaikan dengan lengkap pada waktu yang paling minimal sehingga Algoritma Campbell yang merupakan pengembangan dari Algoritma Johnson mampu memberikan urutan yang baik/urutan yang optimal dalam menyelesaikan problem penjadwalan N Jobs M Mesin.

\section{Hasil Dan Pembahasan}

\subsection{Uji Efektivitas Kasus N Jobs 1 Mesin}

Waktu proses N Jobs 1 Mesin disajikan dalam Tabel 1.

Tabel 1. Tabel Waktu Proses N Jobs 1 Mesin

\begin{tabular}{lllll}
\hline Job I & $\mathrm{J} 1$ & $\mathrm{~J} 2$ & $\mathrm{~J} 3$ & $\mathrm{~J} 4$ \\
\hline Processing time (ti) & 7 & 6 & 8 & 5 \\
\hline
\end{tabular}

\subsubsection{Solusi Mencari Penjadwalan N Jobs 1 Mesin.}

Karena hanya 1 mesin (single) maka proses penjadwalan sesuai dengan urutan job yang dikerjakan. Penjadwalannya yaitu $\mathrm{J} 1 \rightarrow \mathrm{J} 2 \rightarrow \mathrm{J} 3 \rightarrow \mathrm{J} 4$.

\subsubsection{Solusi Mencari Makespan N Jobs 1 Mesin.}

Untuk menghitung nilai Makespan terlebih dahulu dicari waktu tunggu untuk mesin ke1. Karena pada Mesin ke-1 setiap job langsung diproses, maka job-job pada Mesin ke-1 mempunyai waktu tunggu sama dengan nol. Sehingga makespan-nya menjadi:

$\mathrm{MS}=(7+6+8+5)+(0+0+0+0)=26$. 
Gambar 6 merupakan penyajian dari hasil pengujian penjadwalan yang digambarkan dalam sebuah Gantt Chart.

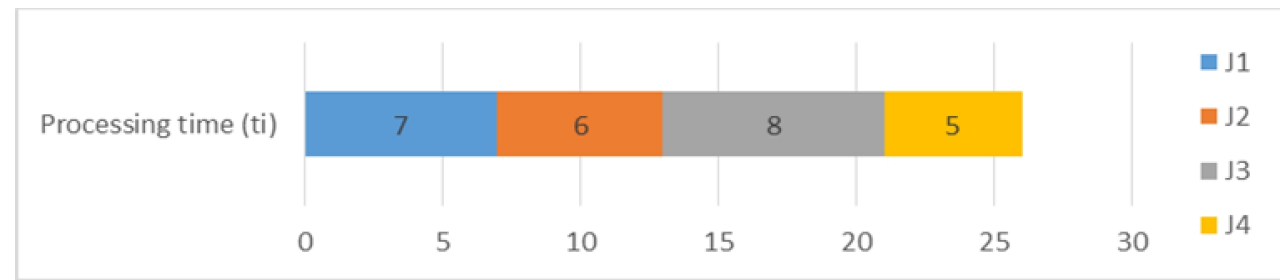

Gambar 6. Gantt Chart 4 Jobs, 1 Mesin

\subsection{Uji Efektivitas Kasus N Jobs 2 Mesin}

Untuk penjadwalan N Jobs 2 Mesin Johnson mengembangkan sebuah algoritma untuk mendapatkan sebuah optimal sequence. Adapun tahapan dari Campbell Johnson yaitu (Nurpasca, 2012): (1) Membuat daftar waktu proses untuk seluruh pekerjaan-pekerjaan tersebut baik pada M-1 atau M-2. (2) Mencari seluruh waktu proses untuk seluruh pekerjaan. Menentukan waktu proses yang minimal. (3) Jika waktu proses minimal berada pada M-1, tempatkan pekerjaan tersebut paling awal dalam urutan. Jika berada pada M-2 maka tempatkan pekerjaan di akhir urutan.(4) Ulangi langkah 2 dan 3 untuk pekerjaan-pekerjaan yang belum dimasukkan ke dalam urutan penjadwalan. Studi kasus untuk N Jobs 2 Mesin akan menggunakan data waktu proses di Tabel 2.

Tabel 2. Waktu Proses Awal N Jobs 2 Mesin

\begin{tabular}{cc|ccccc}
\hline$J o b$ & J1 & J2 & J3 & J4 & J5 & J6 \\
\hline M1 & 4 & 7 & 3 & 12 & 11 & 9 \\
\hline M2 & 11 & 7 & 10 & 8 & 10 & 13 \\
\hline
\end{tabular}

\subsubsection{Solusi Mencari Penjadwalan N Jobs 2 Mesin}

Aturan penjadwalan N Jobs 2 Mesin: (1) Pekerjaan dengan waktu proses terkecil adalah J3, dimana terdapat pada M1, sehingga J3 diletakkan pada penjadwalan seawal mungkin. Kemudian J3 dihilangkan dari tabel tersebut.(2) Waktu proses terkecil berikutnya adalah 4 pada J1, sehingga J1 diurutkan seawal mungkin. (3) Waktu proses terkecil selanjutnya adalah tujuh, tetapi waktu proses tekecil tersebut sama-sama terdapat pada M1 dan M2. Keputusan untuk menjadwalkan J2 seakhir mungkin (posisi ke-6) atau seawal mungkin (posisi ke-3) pada tabel pengurutan, tergantung pada prioritas job (jika ada), jika tidak ada prioritas, J2 dapat ditampilkan pada posisi ke-3 atau ke-6 tanpa mempengaruhi makespan penjadwalan.Waktu proses terkecil berikutnya adalah delapan, yaitu J4. Tabel akhir terdapat pada Tabel 3 atau Tabel 4.

Tabel 3. Urutan Penjadwalan pada Proses Pertama

\begin{tabular}{llllll}
\hline $\mathrm{J} 3$ & $\mathrm{~J} 1$ & $\mathrm{~J} 2$ & $\mathrm{~J} 6$ & $\mathrm{~J} 5$ & $\mathrm{~J} 4$ \\
\hline
\end{tabular}

Tabel 4. Urutan Penjadwalan pada Proses Kedua

\begin{tabular}{llllll}
\hline J3 & J1 & J6 & J5 & J4 & J2 \\
\hline
\end{tabular}

\subsubsection{Solusi Mencari Makespan N Jobs 2 Mesin}

Pada N Jobs 2 Mesin terdapat dua urutan penjadwalan, yaitu J3 $\rightarrow \mathrm{J} 1 \rightarrow \mathrm{J} 2 \rightarrow \mathrm{J} 6 \rightarrow \mathrm{J} 5 \rightarrow \mathrm{J} 4$ dan $\mathrm{J} 3 \rightarrow \mathrm{J} 1 \rightarrow \mathrm{J} 6 \rightarrow \mathrm{J} 5 \rightarrow \mathrm{J} 4 \rightarrow \mathrm{J} 2$ dan disajikan dalam Tabel 5 dan 6.

Tabel 5. Waktu Proses Jadwal Pertama

\begin{tabular}{lrlllll}
\hline$J_{o b}$ & $\mathrm{~J} 3$ & $\mathrm{~J} 1$ & $\mathrm{~J} 2$ & $\mathrm{~J} 6$ & $\mathrm{~J} 5$ & $\mathrm{~J} 4$ \\
\hline $\mathrm{M} 1$ & 3 & 4 & 7 & 9 & 11 & 12 \\
\hline $\mathrm{M} 2$ & 10 & 11 & 7 & 13 & 10 & 8 \\
\hline
\end{tabular}




$$
\begin{array}{ll}
t_{\left[\begin{array}{c}
\text { New } i], j-1 \\
\text { New }
\end{array}\right.}=t_{[i], j-1+I_{[i], j-1}} \\
I_{[i], j} & =\max \left\{0,\left(\sum_{k=1}^{i} t_{[k], j-1}^{\text {New }}-\sum_{k=1}^{i-1} t_{[k], j}-\sum_{k=1}^{i-1} I_{[k], j}\right)\right\} \\
\text { MS } & =(10+11+13+10+8+7)+(3+0+0+0+0+0)=62
\end{array}
$$

Tabel 6. Waktu Proses Jadwal Kedua

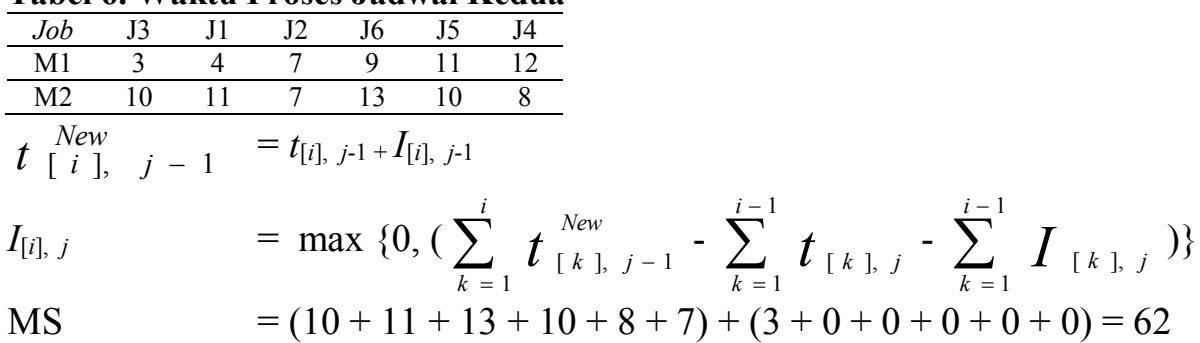

Penyajian dari hasil pengujian penjadwalan mesin produksi $\mathrm{N}$ Jobs 2 Mesin digambarkan dalam bentuk Gantt Chart yang terdapat pada Gambar 7.

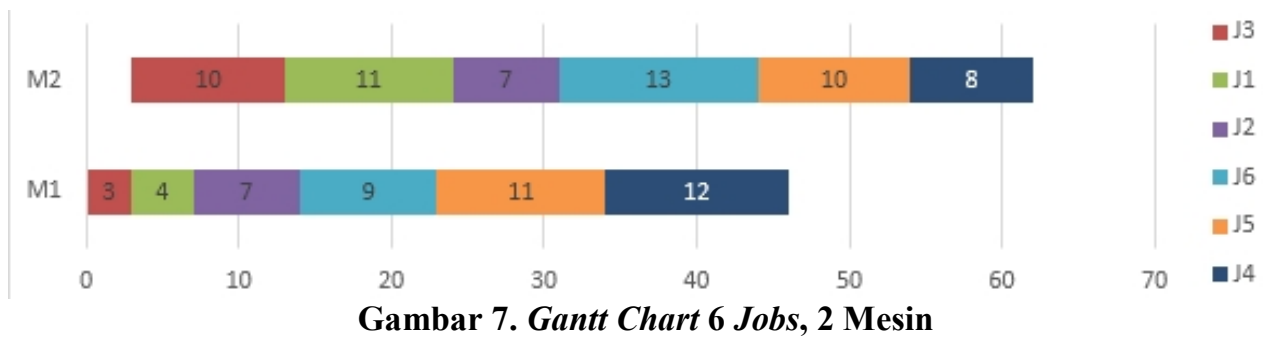

\subsection{Uji Efektivitas Studi Kasus N Jobs M Mesin}

Terdapat 4 job yang diproses pada 4 mesin menggunakan Metode Campbell Dudek and Smith (CDS) dan disajikan pada Tabel 7.

Tabel 7. Waktu Proses Awal N Jobs M Mesin

\begin{tabular}{ccccc}
\hline$J_{o b}$ & Mesin 1 & Mesin 2 & Mesin 3 & Mesin 4 \\
\hline 1 & 5 & 6 & 4 & 5 \\
\hline 2 & 4 & 7 & 3 & 5 \\
\hline 3 & 9 & 5 & 5 & 3 \\
\hline 4 & 6 & 8 & 4 & 1 \\
\hline
\end{tabular}

\subsubsection{Solusi Mencari Penjadwalan N Jobs M Mesin}

Tahapan yang diberikan: (1) Pada set pertama mengambil mesin pertama yaitu M1 diposisikan sebagai M1 dan mengambil mesin terakhir yaitu M4 diposisikan sebagai M2 dan disajikan dalam Tabel 8. Menggunakan bantuan Algoritma Johnson karena pada proses di atas dianggap sebagai penjadwalan N Jobs, 2 Mesin didapat pengurutan J2 $\rightarrow \mathrm{J} 1 \rightarrow \mathrm{J} 3 \rightarrow \mathrm{J} 4$. (2) Set kedua merupakan perhitungan dari penggabungan dua mesin yaitu M12 dan M34. (3) Set terakhir adalah gabungan tiga mesin yaitu M123 dan M234. (4) Penjadwalan Set Akhir disajikan dalam Tabel 9. Penjadwalan yang didapat yaitu J2 $\rightarrow \mathrm{J} 1 \rightarrow \mathrm{J} 4 \rightarrow \mathrm{J} 3$. Dari pengerjaan di atas didapat tiga penjadwalan yaitu $\mathrm{J} 2 \rightarrow \mathrm{J} 1 \rightarrow \mathrm{J} 3 \rightarrow \mathrm{J} 4, \mathrm{~J} 1 \rightarrow \mathrm{J} 3 \rightarrow \mathrm{J} 2 \rightarrow \mathrm{J} 4$ dan $\mathrm{J} 2 \rightarrow \mathrm{J} 1 \rightarrow \mathrm{J} 4 \rightarrow \mathrm{J} 3$.

Tabel 8. Penjadwalan Set Pertama

\begin{tabular}{lll}
\hline$J o b$ & $M 1$ & $M 4$ \\
\hline 1 & 5 & 5 \\
\hline 2 & 4 & 5 \\
\hline 3 & 9 & 3 \\
\hline 4 & 6 & 1 \\
\hline
\end{tabular}

Tabel 9. Hasil Penjadwalan Set Akhir

\begin{tabular}{ccc}
\hline \multirow{2}{*}{ Job $I$} & $M 123$ & $M 234$ \\
\cline { 2 - 3 } & $t_{i 1}+t_{i 2}+t_{i 3}$ & $t_{i 2}+t_{i 3}+t_{i 4}$ \\
\hline 1 & 15 & 15 \\
\hline 2 & 14 & 15 \\
\hline 3 & 19 & 13 \\
\hline 4 & 18 & 13 \\
\hline
\end{tabular}




\subsubsection{Solusi Mencari Makespan N Jobs M Mesin}

Pada penjadwalan $\mathrm{J} 2 \rightarrow \mathrm{J} 1 \rightarrow \mathrm{J} 3 \rightarrow \mathrm{J} 4$ disajikan pada Tabel 10 . Pada penjadwalan $\mathrm{J} 1 \rightarrow \mathrm{J} 3 \rightarrow \mathrm{J} 2 \rightarrow \mathrm{J} 4$ disajikan dalam Tabel 11. Pada penjadwalan $\mathrm{J} 2 \rightarrow \mathrm{J} 1 \rightarrow \mathrm{J} 4 \rightarrow \mathrm{J} 3$ disajikan dalam Tabel 12.

Tabel 10. Waktu Proses ke-1 N Jobs M Mesin

\begin{tabular}{|c|c|c|c|c|c|}
\hline$J o b$ & Mesin 1 & Mesin 2 & Mesin 3 & Mesin 4 & \\
\hline 1 & 5 & 6 & 4 & 5 & \\
\hline 2 & 4 & 7 & 3 & 5 & \\
\hline 3 & 9 & 5 & 5 & 3 & \\
\hline 4 & 6 & 8 & 4 & 1 & \\
\hline$t{ }_{\left[\begin{array}{c}\mathrm{Ner} \\
i\end{array}\right.}$ & $j-1$ & $=t_{[i], j-1}$ & $I_{[i], j-1}$ & & \\
\hline$I_{[i], j}$ & & $=\max$ & $0,\left(\sum_{k=1}^{i}\right.$ & $t_{[k], j-1}^{N e w}$ & $\left.\left.-\sum_{k=1}^{i-1} t_{[k], j}-\sum_{k=1}^{i-1} I_{[k], j}\right)\right\}$ \\
\hline MS & & $=\sum_{i=1}^{n}$ & $i], m+$ & $\sum_{i=1}^{n} I$ & ${ }_{i], m}=(5+5+3+1)+(14+2+2+5)=37$ \\
\hline
\end{tabular}

Tabel 11. Waktu Proses ke-2 N Jobs M Mesin

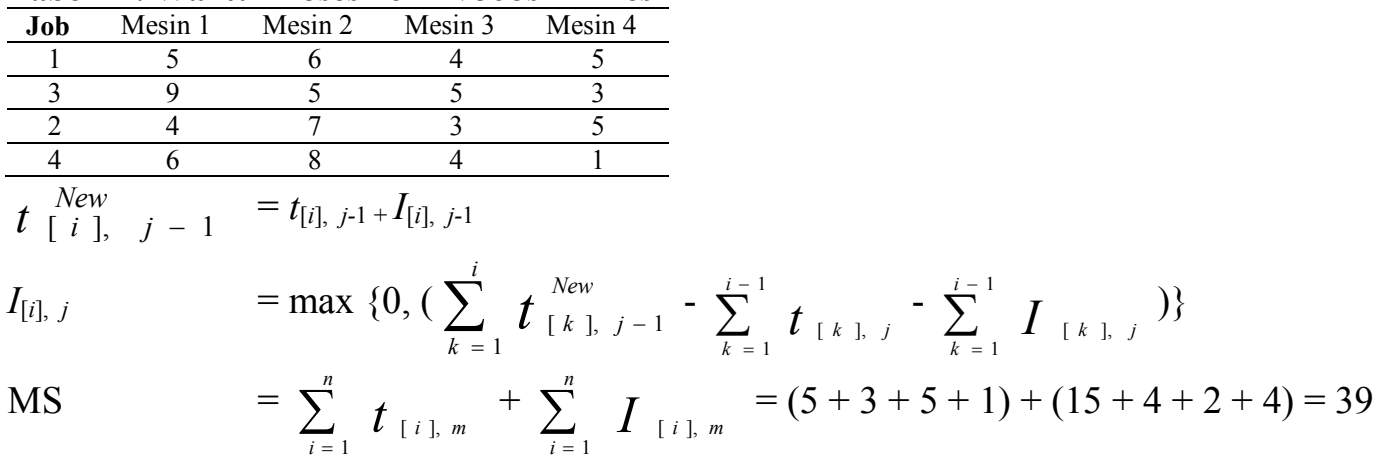

Tabel 12. Waktu Proses ke-3 N Jobs M Mesin

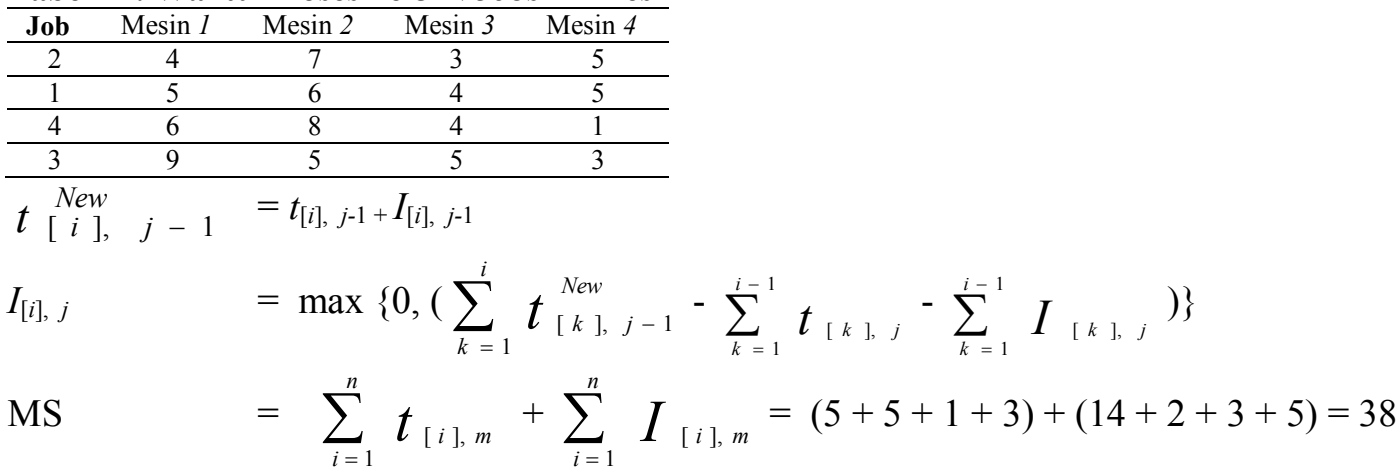

Pada kasus N Jobs, M Mesin, terdapat banyak penjadwalan tetapi yang diprioritaskan pertama kali adalah penjadwalan yang menghasilkan makespan minimum, seperti Gambar 8 .

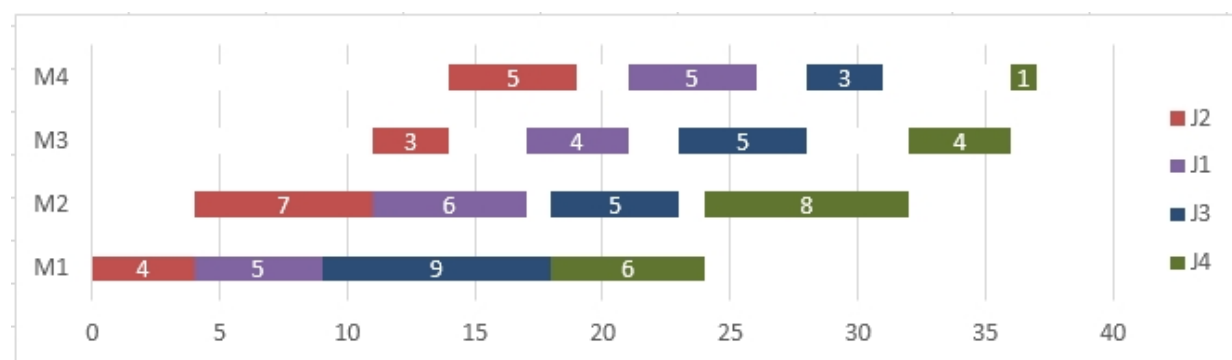

Gambar 8. Gantt Chart 4 Jobs, 4 Mesin 


\section{Kesimpulan Dan Saran}

Berdasarkan analisis dan pengujian di atas maka dapat diambil beberapa kesimpulan yaitu: (1) Penerapan Algoritma Johnson dalam aplikasi dapat digunakan untuk menghasilkan jadwal dengan makespan yang minimum untuk tipe produksi dengan N Jobs 2 Mesin yang statis dan flowshop. (2) Penerapan Algoritma Campbell dalam aplikasi, yang merupakan pengembangan dari Algoritma Johnson dapat digunakan untuk menghasilkan jadwal dengan makespan minimum pada tipe produksi dengan N Jobs M Mesin yang statis dan flowshop. (3) Jadwal dengan makespan minimum yang dihasilkan untuk jumlah mesin produksi lebih dari satu mesin, masih mungkin mengandung waktu tunggu. Waktu tunggu ini terjadi karena sebuah mesin menunggu (idle) karena job yang harus diprosesnya masih diproses pada mesin yang lain, atau karena sebuah job menunggu untuk diproses oleh sebuah mesin karena mesin tersebut masih memproses job yang lain.

Keuntungan menggunakan Algoritma Johnson dan Campbell adalah perusahaan dapat menghasilkan jadwal yang mempunyai makespan yang minimum pada penjadwalan mesin produksi. Sedangkan kekurangannya adalah pada metode Jhonson dan Campell hanya bisa digunakan pada tipe penjadwalan statis dan belum bisa diuji coba pada jumlah mesin yang sangat banyak atau ribuan mesin.

Kontribusi yang bisa diberikan dari penelitian dengan komparasi antara Algoritma Johnson dan Campbell adalah dapat memberikan kemudahan kepada perusahaan yang bergerak dibidang produksi khususnya mesin produksi dengan pola flowshop statis.

Adapun saran yang dapat disampaikan dalam rangka pengembangan Sistem Penjadwalan Mesin Produksi dalam mencari penjadwalan yang baik dan makespan yang minimum adalah diharapkan aplikasi ini dikembangkan untuk tipe penjadwalan job shop ataupun dinamis dengan algoritma yang sesuai.

\section{Referensi}

Aryetta, Risky. 2007. Penjadwalan Mesin Dengan Metode CDS (Campbell, Dudeck \& Smith) dan Metode Palmer Pada Bagian Casting Shop di PT. Indonesia Asahan Aluminium (Inalum). Medan: Fakultas Teknik Universitas Sumatera Utara.

Christianta, Y., Sunarni, T. 2012. Usulan Penjadwalan Mesin Produksi Menggunakan Metode Campbell Dudek And Smith. Palembang: Jurusan Teknik Industri STT Palembang.

Badworth, D. 1987. Integrated Production Control System, New York: John Wiley \& Sons, Inc.

Dewi, F.G. 2005. Penjadwalan Pembuatan Box Aluminium Untuk Meminimalkan Makespan. Prosiding SEMNAS, Institut Teknologi Sepuluh Nopember, Surabaya.

Farouq, Eko. 2013. Simulasi Aturan Johnson Untuk Penjadwalan Produksi Flowshop di Perusahaan Furniture. Malang: Jurusan Ilmu Komputer Program Studi Teknologi Informasi dan Ilmu Komputer Universitas Brawijaya.

Ginting, Rosnani. 2009. Penjadwalan Mesin. Yogyakarta: Graha Ilmu.

Masruroh, Nisa. 2008. Analisa Penjadwalan Produksi dengan Menggunakan Metode Campbell Dudeck Smith, Palmer dan Dannenbring di PT. Loka Refraktoris Surabaya. Surabaya: Jurusan Teknik Industri Fakultas Teknik Industri Universitas Veteran UPN Surabaya.

Novriansyah. 2006. Peningkatan Perencanaan Penjadwalan dengan Metode Campbell Dudeck and Smith. Palembang: Paper Jurusan Teknik Industri Universitas Bina Darma.

Nurpasca, Irandra. 2012. Penjadwalan Produksi Flowshop Untuk Meminimasi Makespan dengan Analisis Perbandingan Metode Heuristic, Pour dan Campbell, Dudeck and Smith (CDS) pada Lantai. Telkom University, Bandung. 